\title{
Gross Anatomy of the Stomach of the Cervus Elaphus barbarus
}

\author{
Anatomía Macroscópica del Estómago del Ciervo Elaphus barbarus
}

\author{
Hassen Jerbi* \& William Pérez ${ }^{* *}$
}

JERBI, H. \& PÉREZ, W. Gross anatomy of the stomach of the cervus Elaphus barbarus. Int. J. Morphol., 31(2):388-391, 2013.

SUMMARY: The barbary stag is an intermediate feeder ruminant of the Cervidae family. The macroscopic anatomy of the stomach in one adult barbary stag was described. The stomach of the barbary stag was composed of the four classic compartments of the ruminants. The weight of the full stomach was $10.5 \mathrm{Kg}$. The ruminal papillae were distributed unevenly in the rumen. The maximum height of the cristae reticuli was $0.2 \mathrm{~cm}$. The cellulae reticuli were mostly undivided. The curvatura omasi measured $15.0 \mathrm{~cm}$ and the omasum had 15 primary, 10 secondary, 10 tertiary and 17 cuaternaryLaminae omasi. The abomasum had about 12 plicae spirales abomasi.We concluded that the stomach morphology of the barbary stag had characteristics of other intermediate feeder ruminants.

KEY WORDS: Abomasum; Abdomen; Cervidae; Forestomach; Proventriculus.

\section{INTRODUCTION}

The classification of ruminants into three groups according to their feeding types (browsers, intermediate feeders, grazers) has been linked to anatomical studies, mainly of African, European, and North American species (Hofmann,1973, 1988). Most cervids are considered either browsers (i.e., natural diet consisting mainly of dicotyledonous forage, like tree foliage, herbs, or wild fruits) or intermediate feeders (i.e., consuming monocotyledonous forage - grasses - to a certain degree, mostly dependent on seasonal variation in forage availability) (Hofmann, 1985).

The barbary stag (Cervus elaphus barbarus), or atlas deer is a subspecies of red deer that is the only member of the deer family that is native to Africa in the countries of Algeria, Tunisia and Morocco.

Cervus elaphus was considered an intermediate feeder, with a tendency to include more browse than grass intheir natural diet (Gebert\&Verheyden-Tixier, 2001).

In this work we described the stomach of one male Cervus elaphus barbarus of Tunisia, North Africa. According to our knowledge there is no available information on the macroscopic anatomy of the stomach of Cervus elaphus barbarus.

\section{MATERIAL AND METHOD}

One adult male Cervus elaphus barbarus from Tunisia was used in this study. The age of the animal was 2 years. The body condition was excellent and body weight was $60.0 \mathrm{Kg}$. The animal was dissected immediately after being found dead. The ventral abdominal wall was removed. The stomach was removed after sectioning the oesophagus just prior to the diaphragm and the pylorus just before the duodenum. Stomach content was measured by weighing the unopened organ and re-weighing it after it had been opened and contents rinsed with tap water and dried with paper towels. Anatomical measurements were taken following standard procedures used by Hofmann (1973) or Clauss indications (personal communication); in brief, the ruminoreticulum was placed on its left side, and the height and length of the rumen and the reticulum, the length of the Curvatura omasa were measured with soft measuring tape. After incision and emptying of the stomach compartments, the dimensions of the Ostia intraruminale, ruminoreticulare and reticuloomasale were measured by tape; the thickness of the cranial and caudal rumen pillars, and the maximum height of the reticular crests and papillae unguiculiformes were measured with calipers. The Lamina omasi were removed and counted according to their order. The stomach full and empty weights were registered.

\footnotetext{
* Service d'Anatomie, Ecole Véterinaire Sidi Thabet. CP 2020, Tunisie.

** Área de Anatomía, Facultad de Veterinaria, Lasplaces 1620, 11600 Montevideo, Uruguay
} 
Pictures were taken with a Sony digital camera. Terms are used in agreement with the NominaAnatomica Veterinaria (2005).

\section{RESULTS}

The stomach of the barbary stagwas composed of the four classic compartments of the ruminants (Figs. 1, 2, 3). The weight of all the full stomach was $10.5 \mathrm{Kg}$. The weight of the empty rumen + reticulum was $2.0 \mathrm{Kg}$.

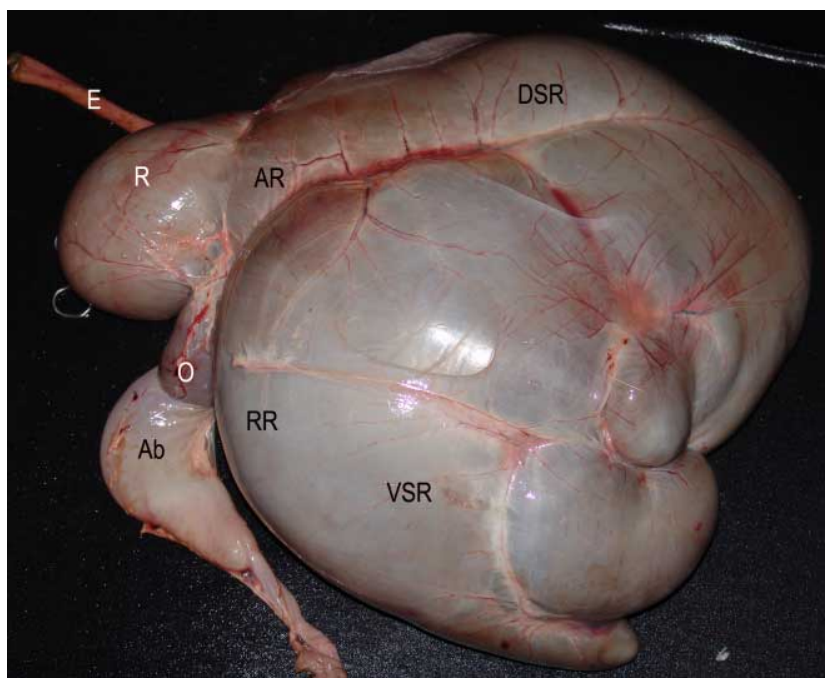

Fig. 1. Left view of the stomach of the Cervus elaphus barbarus. E: Esophagus; DSR: Saccus dorsalis; AR: Atrium ruminis; RR: Ruminal recess; VSR: Saccus ventralis; R: Reticulum; O: Omasum; Ab: Abomasum.

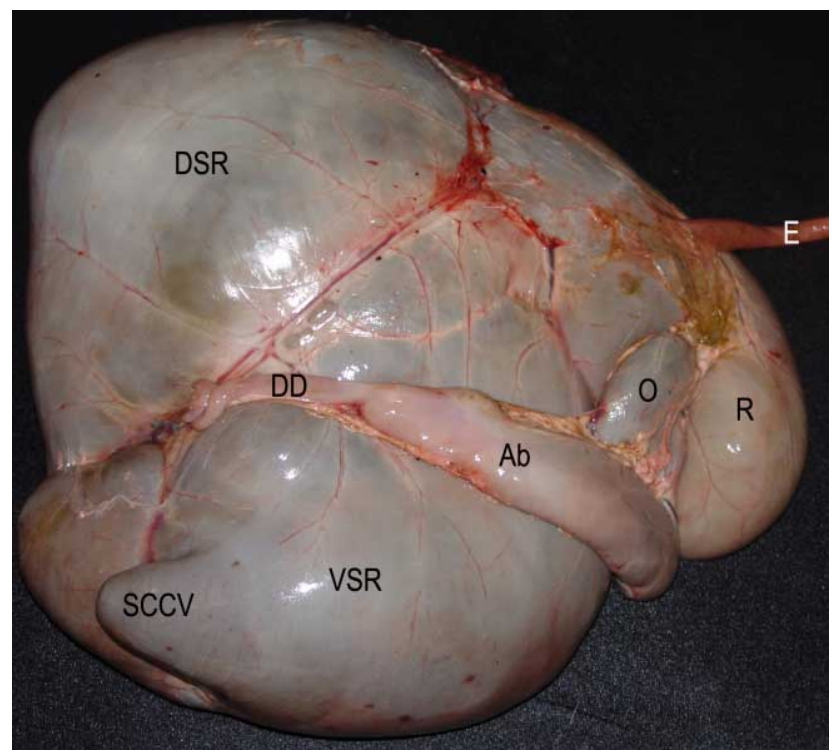

Fig. 2. Right view of the Cervus elaphus barbarus stomach. E: Esophagus; DSR: Saccusdorsalis; VSR: Saccusventralis; SSCV: Saccus cecus caudoventralis; R: Reticulum; O: Omasum; Ab: Abomasum, DD: Descending duodenum.
Lengths of the dorsal and ventral sacs of the rumen were $41.0 \mathrm{~cm}$ and $39.0 \mathrm{~cm}$, respectively. The height of the rumen was $43.0 \mathrm{~cm}$. The Saccus caecus caudoventralisnot extended more caudally than the Saccus caecus caudodorsalis (Fig. 1). The dorsal sac communicated with the ventral sac by the Ostium intraruminale, whose border was formed by the ruminal pillars, and which measured diameters were 16 $\mathrm{x} 18 \mathrm{~cm}$. We not found notorious differences in the contents of the dorsal and ventral sacs of the rumen. The ruminal pillar thickness was $20.0 \mathrm{~mm}$ and $10.0 \mathrm{~mm}$ for the cranial and caudal pillars, respectively. The Ostium ruminoreticulare measured 4.0 × $4.0 \mathrm{~cm}$.

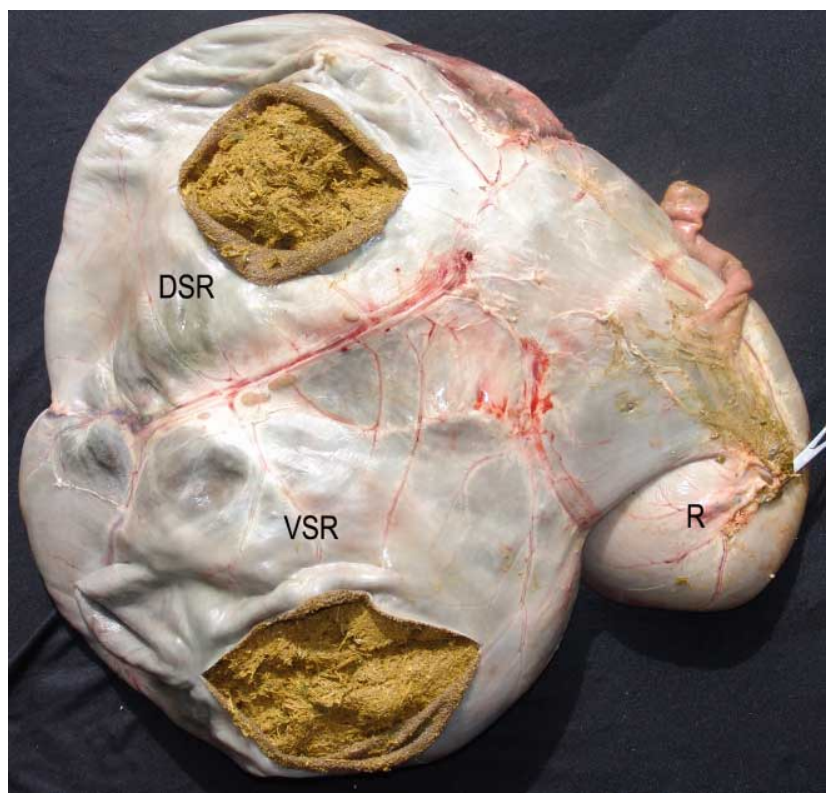

Fig. 3. Rumen partially opened in dorsal and ventral sacs. DSR: Saccus dorsalis; VSR: Saccus ventralis; R: Reticulum.

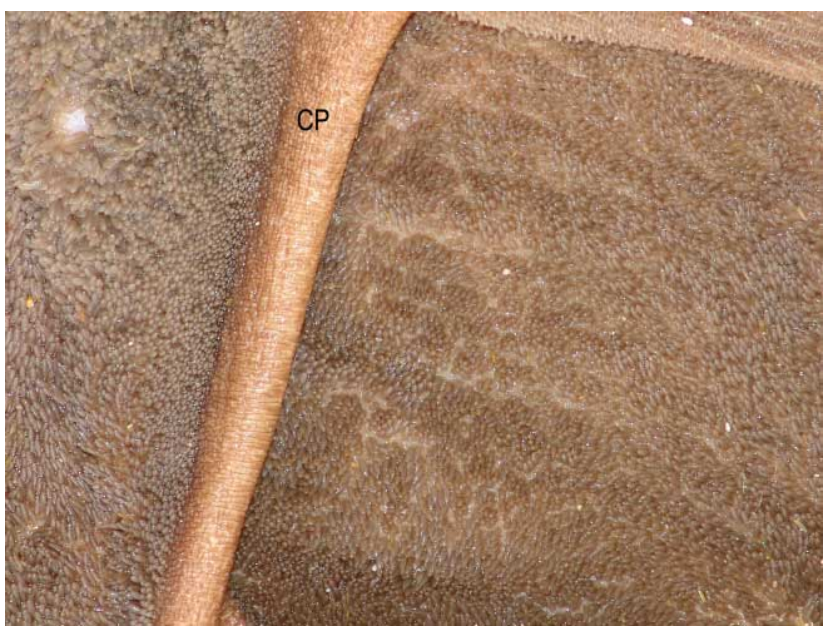

Fig. 4. Internal view of the Cranial pillar (CP) and adjacent parts of the rumen of the Cervus elaphus barbarus stomach. 
The ruminal papillae were distributed unequally in the rumen, and were more large and abundant within the atrium and in the two saccuscecus. The papillae were absent indorsal part of the dorsal sac. The ruminal pillars had no papillae (Fig. 4). The ruminal papillae gradually continued with the cristae reticuli cranially to the Plica ruminoreticularis.

The height of the reticulum was $11.0 \mathrm{~cm}$ and the craniocaudal length was $7.0 \mathrm{~cm}$. The maximum height of the cristae reticuli was $0.2 \mathrm{~cm}$. The Cellulae reticuli were mostly undivided and some of them contained secondary (Fig. 5). They were broader and deeper near the greater curvature and were becoming smaller toward the lesser curvature. The maximum length of Papillae unguiculiformes was $0.15 \mathrm{~cm}$. The reticulo-omasal orifice measured $2.0 \mathrm{~cm}$ in diameter.

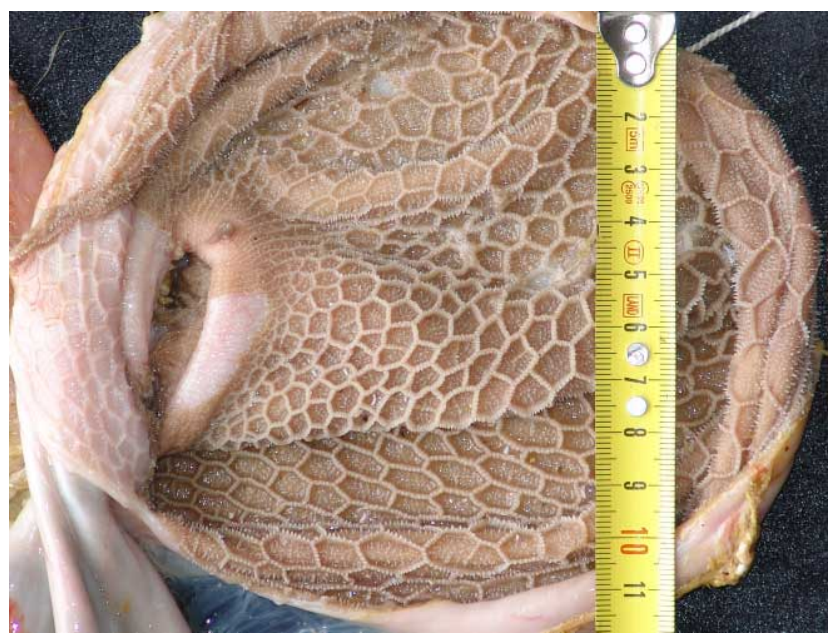

Fig. 5. Internal view of the reticulum of the Cervus elaphus barbarus stomach.

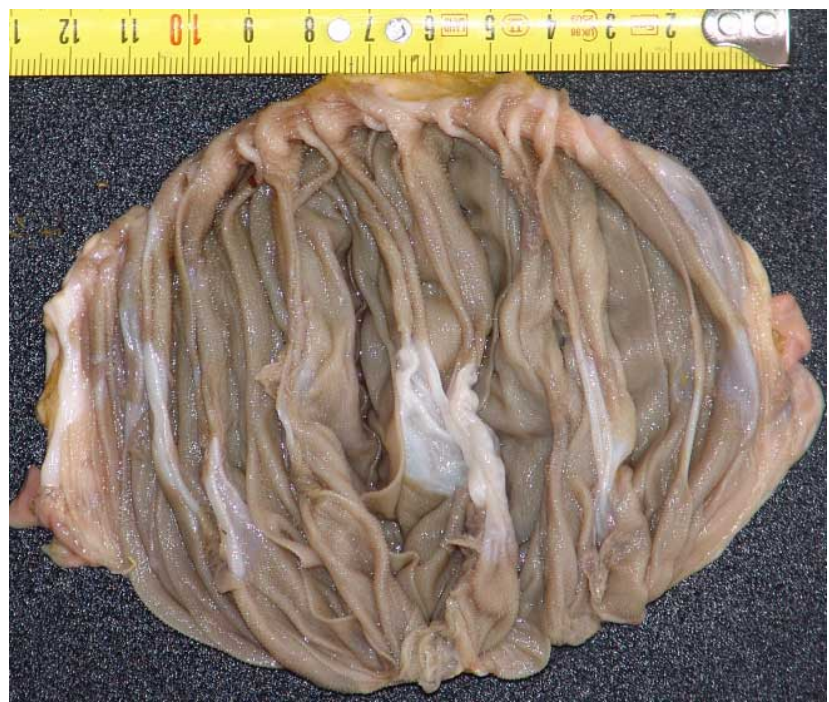

Fig. 6. Opened omasum of the Cervus elaphus barbarus stomach.
The weight of full omasum was $0.4 \mathrm{Kg}$, and the empty weight was $0.3 \mathrm{Kg}$. The Curvatura omasi measured $15.0 \mathrm{~cm}$. The omasum had 15 primary, 10 secondary, 10 tertiary and 17 cuaternaryLaminae omasi(Figs. 6, 7) and the sides of the laminae were marked by the presence of Papillae omasi.

The abomasum full weight was $0.5 \mathrm{Kg}$, and the empty weight was $0.25 \mathrm{Kg}$. The length of the curvature major was 29.0 $\mathrm{cm}$ and the length of the curvatura minor was $20.0 \mathrm{~cm}$. The abomasum had about 12 plica spirales abomasi and the first one conformed the Velo abomasicum(Fig. 8), and a small Torus pyloricus was present.

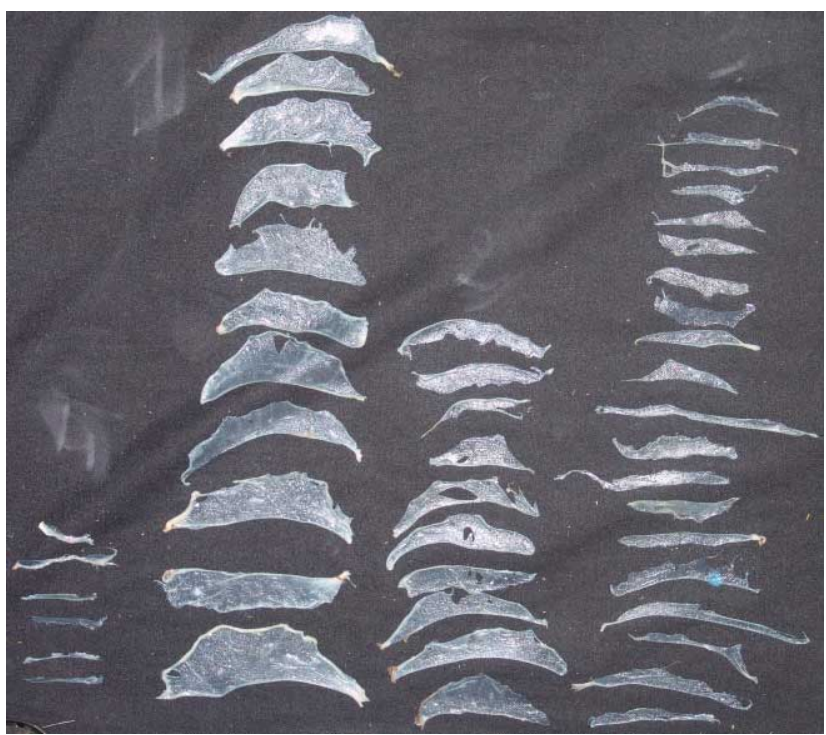

Fig. 7. Isolated fourth orders of Lamina omasi of the Cervus elaphus barbarus stomach.

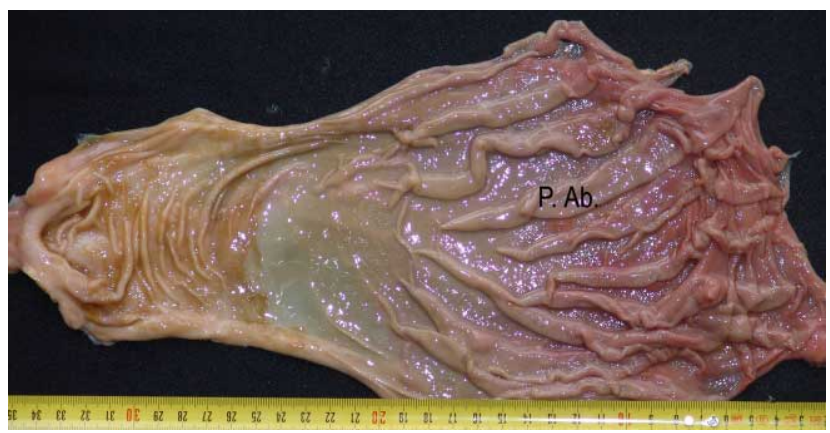

Fig. 8. Internal view of the Abomasum of the Cervus elaphus barbarus stomach.P. Ab.: Plica spiralis abomasi.

\section{DISCUSSION}

This is the first anatomical description of the stomach of the Cervus elaphus barbarus of Tunisia.An important limitation of this study is the fact that we used only one animal. 
To draw conclusions about the size of the different parts of the stomach we need to dissect more animals and not only consider the external dimensions of the organs. In red deer Clauss et al., (2009) found more watery fluid at ventral sac of the rumen than in the rest of the rumen, but in our animal we found no differences. This may be due to the diet consumed by the animal.

The intraruminal papillation pattern and the unpapillated rumen pillars were similar to those species that are characterized by a higher proportion of grass in their natural diet (Clausset al., 2009).

The finding of the median reticular crests is different from the great reticular crests typical for grazing ruminants (Clauss et al., 2010). Grazing ruminants have in general higher reticular crests than browsers, and more pronounced secondary, tertiary and even quaternary crests (Hofmann, 1973;Langer, 1988). Hofmann (1973, 1988, 1989) and Langer (1988) and Clauss (2006) confirmed that ruminants with a higher proportion of grass in their natural diet have larger omasa. The omasum of our studied animal was large and has a great number of four orders of Lamina omasi.

To conclude, the anatomy of the stomach of Cervus elaphus barbarus had characteristics similar to others grazing or intermediate feeder ruminants.

JERBI, H. \& PÉREZ, W. Anatomía macroscópica del estómago del ciervo Elaphus barbarus. Int. J. Morphol., 31(2):388-391, 2013.

SUMMARY: El ciervo de Berbería es un rumiante perteneciente a la familia Cervidae family. Se describió la anatomía macroscópica del estómago de un ciervo de Berbería. El estómago del ciervo estaba compuesto por los clásicos cuatro componentes de los rumiantes. El peso lleno del estómago fue de 10,5 Kg. Las papilas ruminales estaban distribuidas de manera desigual en el rumen. La altura máxima de las crestas reticulares fue de $0,2 \mathrm{~cm}$. La mayoría de las celdas reticulares estaban divididas. La curvatura del omasi medía $15,0 \mathrm{~cm}$ y la del omasum presentaba 15 láminas primarias, 10 secundaria, 10 terciarias y 17 cauternarias. El abomasum presentaba alrededor de 12 pliegues espirales. Concluimos que la morfología del estómago del ciervo de Berbería es semejante al de otros rumiantes.

KEY WORDS: Abomasum; Abdomen; Cervidae; Forestomach; Proventriculus.

\section{REFERENCES}

Clauss, M.; R. R. Hofmann; J. Hummel; J. Adamczewski; K. Nygren; C. Pitra\& S. Reese. The macroscopic anatomy of the omasum of free-ranging moose(Alcesalces) and muskoxen (Ovibos moschatus) and a comparison of the omasallaminal surface area in 34 ruminant species. J. Zoology, 270:346-58, 2006.

Clauss, M.; Hofmann, R. R.; Fickel, J.; Streich, W. J.; Hummel, J. \& Foundation, G. W. The intraruminal papillation gradient in wild ruminants of different feeding types: Implications for rumen physiology. J. Morphology, 270: 929-2, 2009.

Clauss, M.; Hofmann, R. R.; Streich,W. J.; Fickel, J. \& Hummel, $\mathrm{J}$. Convergence in the macroscopic anatomy of the reticulum in wild ruminant species of different feeding types and a new resulting hypothesis on reticular function. J. Zoology, 281:1225,2010 .

Gebert, C.; Verheyden-Tixier, H. Variations of diet composition of red deer (Cervus elaphus) in Europe. Mammal Review, 31:189201,2001 .

Hofmann, R. R. The ruminant stomach. Nairobi. East African Literature Bureau,1973.

Hofmann, R. R. Morphophysiological evolutionary adaptations of the ruminant digestive system. In Aspects of digestive physiology in ruminants: 1-20. Dobson, A. \& Dobson, M. (Eds). Ithaca, NY: Cornell University Press.1988.

Hofmann, R. R. Evolutionary steps of ecophysiological adaptation and diversification of ruminants: a comparative view of their digestive system. Oecologia, 78:443-57,1989.

Nomina Anatómica Veterinaria(NAV). 5th ed. International Committee on Veterinary Gross Anatomical Nomenclature (I.C.V.G.A.N.) Available online at: http://www.wava-amav.org/ Downloads/nav_2005.pdf. Downloaded on 20 November 2011.2005.

Correspondence to:

Dr. Williams Pérez

Área de Anatomía

Facultad de Veterinaria

Lasplaces 1620, 11600

Montevideo,

URUGUAY

Email: vetanat@gmail.com

Received: $10-07-2012$

Accepted: 25-02-2013 